\title{
Effects of cryoprotectants and low temperatures on hatching and abnormal embryo development of Prochilodus lineatus (Characiformes: Prochilodontidae)
}

\author{
Raphael S. Costa ${ }^{1}$, Fabrício M. S. de Souza ${ }^{2}$, José A. Senhorini ${ }^{3}$, \\ Rosicleire Veríssimo-Silveira ${ }^{2}$ and Alexandre Ninhaus-Silveira ${ }^{2}$
}

This study evaluated the effect of the cryoprotectants and the low temperatures on the embryonic development of Prochilodus lineatus, describing their main morphological alterations. On chilling sensitivity test, the survival rates at the twenty somites stage $(20 \mathrm{~S})$ were $53.6 \%$ at $0^{\circ} \mathrm{C}$, and $100 \%$ in $5^{\circ} \mathrm{C}$. To test toxicity, the embryos were exposed to a graded series of 1,2-Propanediol (PROP), dimethyl sulfoxide $\left(\mathrm{Me}_{2} \mathrm{SO}_{4}\right)$ and glycerol (GLY), terminating in a solution of high osmolarity. There was no significant difference in the embryos survival of toxicity test between series of PROP and $\mathrm{Me}_{2} \mathrm{SO}_{4}$ in the $6 \mathrm{~S}$ and $20 \mathrm{~S}$. In the cooling protocols, were evaluated the effects of low temperature associated with cryoprotectants. At $5^{\circ} \mathrm{C}$, PROP showed survival rates above $75 \%$ in the gastrula stage $(\mathrm{G})$ and above $90 \%$ in the $6 \mathrm{~S}$ and $20 \mathrm{~S}$ stages. High rates of abnormalities were observed, and the most recurrent were: small bodies, fins presenting uncontrolled cell growth, membrane rupture, and retraction. These results demonstrate the need to use cryoprotectant solutions, even when there is no ice nucleation, and, on the other hand, shows that high cryoprotectant concentrations promote numerous morphological lesions, compromising normal embryonic development.

Keywords: Cooling, Cryopreservation, Injuries, Morphology, Toxicity.

Este estudo avaliou os efeitos dos crioprotetores e das baixas temperaturas no desenvolvimento embrionário de Prochilodus lineatus, descrevendo suas principais alterações morfológicas. Nos testes de sensibilidade ao frio, as taxas de sobrevivência, no estágio de vinte somitos $(20 \mathrm{~S})$, foram de $53,6 \%$ a $0^{\circ} \mathrm{C}$ e $100 \%$ a $5^{\circ} \mathrm{C}$. Nos testes de toxicidade, os embriões foram expostos a uma série graduada dos crioprotetores: 1,2-Propanediol (PROP), dimetilsulfóxido $\left(\mathrm{Me}_{2} \mathrm{SO}_{4}\right)$ e glicerol (GLY), terminando em uma combinação de alta osmolaridade. Não houve diferença significativa na sobrevivência dos embriões nas séries do PROP e $\mathrm{Me}_{2} \mathrm{SO}_{4}$ nos estágios de $6 \mathrm{~S}$ e 20S. Nos protocolos de resfriamento, foram avaliados os efeitos da baixa temperatura associados as séries crioprotetoras. A $5^{\circ} \mathrm{C}$, o PROP apresentou taxas de sobrevivência acima de $75 \%$ no estádio de gástrula $(\mathrm{G})$ e acima de $90 \%$ nos estádios $6 \mathrm{~S}$ e $20 \mathrm{~S}$. Foram observadas altas taxas de anormalidades sendo as mais recorrentes: corpos pequenos, nadadeiras apresentando crescimento celular descontrolado, ruptura da membrana e retração vitelínica. Estes resultados demonstram a necessidade do uso das soluções crioprotetoras, mesmo não havendo nucleação de gelo e, em contrapartida, demonstra que as elevadas concentrações crioprotetoras promovem numerosas lesões morfológicas, comprometendo o desenvolvimento embrionário.

Palavras-chave: Criopreservação, Injúria, Morfologia, Resfriamento, Toxicidade.

\section{Introduction}

Cryopreservation of fish embryos is a highly complex technique because of the physiological and structural features presented by oocytes and embryos, such as a strong relationship between area and volume and a complex system of compartments (perivitelline space, yolk, yolk syncytial layer, and blastoderm) that have different permeation rates. These factors complicate the development and application of deep cryopreservation protocols (Hagedorn et al., 1997b; Robles et al., 2003).

\footnotetext{
1Pós-Graduação em Biologia Animal, Universidade Estadual Paulista “Júlio de Mesquita Filho", Rua Cristóvão Colombo, 265, 15054-000 São José do Rio Preto, SP, Brazil. costa_rs@yahoo.com.br (corresponding author)

${ }^{2}$ Departamento de Biologia e Zootecnia, Faculdade de Engenharia, Universidade Estadual Paulista "Júlio de Mesquita Filho", Av. Brasil, 56, 15085-000 Ilha Solteira, SP, Brazil. (FMSS) fabricio.marcal@hotmail.com, (RVS) rosiverissimo@bio.feis.unesp.br, (ANS) ninhaus@bio.feis.unesp.br ${ }^{3}$ Centro Nacional de Pesquisa e Conservação da Biodiversidade Aquática Continental, Instituto Chico Mendes de Conservação da Biodiversidade, Rodovia Pref. Euberto Nemésio Pereira de Godoy (SP 201), km 6,5, 13630-970 Pirassununga, SP, Brazil. jose.senhorini@icmbio.gov.br
} 
Consequently, the cooling of biological material to near $0^{\circ} \mathrm{C}$ is becoming an alternative for fish production and scientific research, allowing embryogenesis to be delayed without reducing the integrity and viability of embryos caused by nucleation of ice crystals (Robles et al., 2003). In addition, studies allow a better understanding of processes of exposure to the cryoprotectants and low temperatures serve as a basis in cryogenic protocols (Hagedorn et al., 1997b).

Some fish embryos are sensitive to low temperatures (Zhang, Rawson, 1995; Dinnyés et al., 1998), which compromise their metabolism (Desai et al., 2015) and result in changes in their embryonic development (NinhausSilveira et al., 2008). However, temperature sensitivity is variable and dependent upon species, tissue, and cell characteristics and embryonic stage (Dinnyés et al., 1998; Ninhaus-Silveira et al., 2008).

Despite the absence of ice crystals, the cooling of biological materials still requires the use of specific substances that protect cell components from excessive cold (Neves et al., 2012). These substances, which are derived from different chemical groups, are called cryoprotectants and share similar functions of reducing the cryoscopic point of a solution (Robles et al., 2003), promoting cell dehydration, and protecting biomembranes. These products are divided into two groups: those that diffuse across cell membranes (dimethyl sulfoxide, propylene glycol, glycerol, etc.), known as internal cryoprotectants, and others, which do not penetrate cells (sugars and proteins), known as external cryoprotectants (Isayeva et al., 2004; Fornari et al., 2011). These substances are considered to have a key role in the cryopreservation process, but it is necessary to determine both the type and ideal concentration necessary to prevent possible embryo damage by exposure to low temperatures, ensure non-toxicity, and provide adequate embryonic dehydration (Harvey et al., 1983).

In order to maximize performance and reduce toxic effects, many studies have sought increased permeability of tissues and embryonic cells to cryoprotectants, reducing their concentration and diffusion time and hence, the dehydration period of biological material (Suzuki et al., 1995; Ninhaus-Silveira et al., 2008; Robles et al., 2009). One solution adopted for some species is removal or permeation of the chorionic membrane with enzyme solutions (Robles et al., 2003; Ninhaus-Silveira et al., 2008).

The studied species, Prochilodus lineatus (Valenciennes, 1837), is a neotropical fish widely distributed in the Paraná, Paraguai, and Paraíba do Sul river basins, with great ecological and commercial importance (Castro et al., 2004). It is considered a good biological model that reproduces in captivity and has some of the reproductive features common to most neotropical rheophilic fishes, such as prolificity, non-adhesive eggs, fast embryonic development, and a large yolk sac and perivitelline space (Ninhaus-Silveira et al., 2006; Oliveira-Almeida et al., 2014).
In addition, structural and ultrastructural characteristics of $P$. lineatus embryos in all stages of embryogenesis have been described (Ninhaus-Silveira et al., 2006). This study aimed to evaluate the sensitivity of three embryonic stages $[50 \%$ epiboly $(\mathrm{G})$ and six $(6 \mathrm{~S})$ and twenty somites $(20 \mathrm{~S})]$ of $P$. lineatus embryos, exposed to temperatures of 0 and $5^{\circ} \mathrm{C}$, to cooling protocols based on the following cryoprotectant substances: PROP, $\mathrm{Me}_{2} \mathrm{SO}_{4}$, and GLY. We also aimed to evaluate the main morphological changes promoted by the cooling process.

\section{Material and Methods}

Embryos. Embryos of $P$. lineatus were obtained by artificial breeding from mature adult specimens belonging to the Centro Nacional de Pesquisas e Conservação de Peixes Continentais - CEPTA/ICMBIO, Pirassununga, São Paulo, Brazil. A pool of four female oocytes and sperm from three males were used to obtain the embryos. The eggs were incubated in vertical 60 -L incubators with a continuous flow of water at $28 \pm 1{ }^{\circ} \mathrm{C}$ and, when the required embryonic stages were reached, were separated into samples of $139 \pm 11$ viable embryos and placed under experimental treatment conditions. Three stages of embryonic development were used: Gastrula stage (3 hours post fertilization - hpf), 6 somites stage $(7.5 \mathrm{hpf})$ and 20 somites stage ( $9 \mathrm{hpf})$.

The representative material of the species used in this study was deposited in the collection of the Laboratório de Ictiologia at the Universidade Estadual Paulista, São José do Rio Preto-SP (IBILCE), voucher number DZSJRP 21130.

Embryo chill sensitivity. Embryos were placed in $250-\mathrm{mL}$ beakers filled with $150 \mathrm{~mL}$ water, without any cryoprotective solutions, and placed in a BOD type incubator (Cienlab, Brazil) where they remained for a period of $12 \mathrm{~h}$ at temperatures of 0 or $5^{\circ} \mathrm{C}$. An experimental control was performed by keeping embryos to develop at room temperature $\left(28 \pm 1^{\circ} \mathrm{C}\right)$. After the embryo chill, the embryonic temperature was increased gradually until reaching the ambient temperature $\left(28 \pm 1^{\circ} \mathrm{C}\right)$.

Embryo sensitivity to cryoprotectant protocols. Each treatment started with chorionic membrane permeabilization using pronase-E enzyme $(0.2 \mathrm{M} / 10$ s) (Ninhaus-Silveira et al., 2008). These embryos were exposed for 20 min (Suzuki et al., 1995; Zhang, Rawson, 1995) to three main internal cryoprotectant solutions (glycerol - GLY, dimethyl sulfoxide - $\mathrm{Me}_{2} \mathrm{SO}_{4}$ and 1,2-propanediol - PROP). The methodologies of exposition had four immersion sequences steps, of five minutes each. The first three steps were performed in solutions containing a main internal cryoprotectant alone, and the fourth step in a high osmolarity solution, combining internal and external cryoprotectants (Sucrose - SUC) (Fig. 1). 


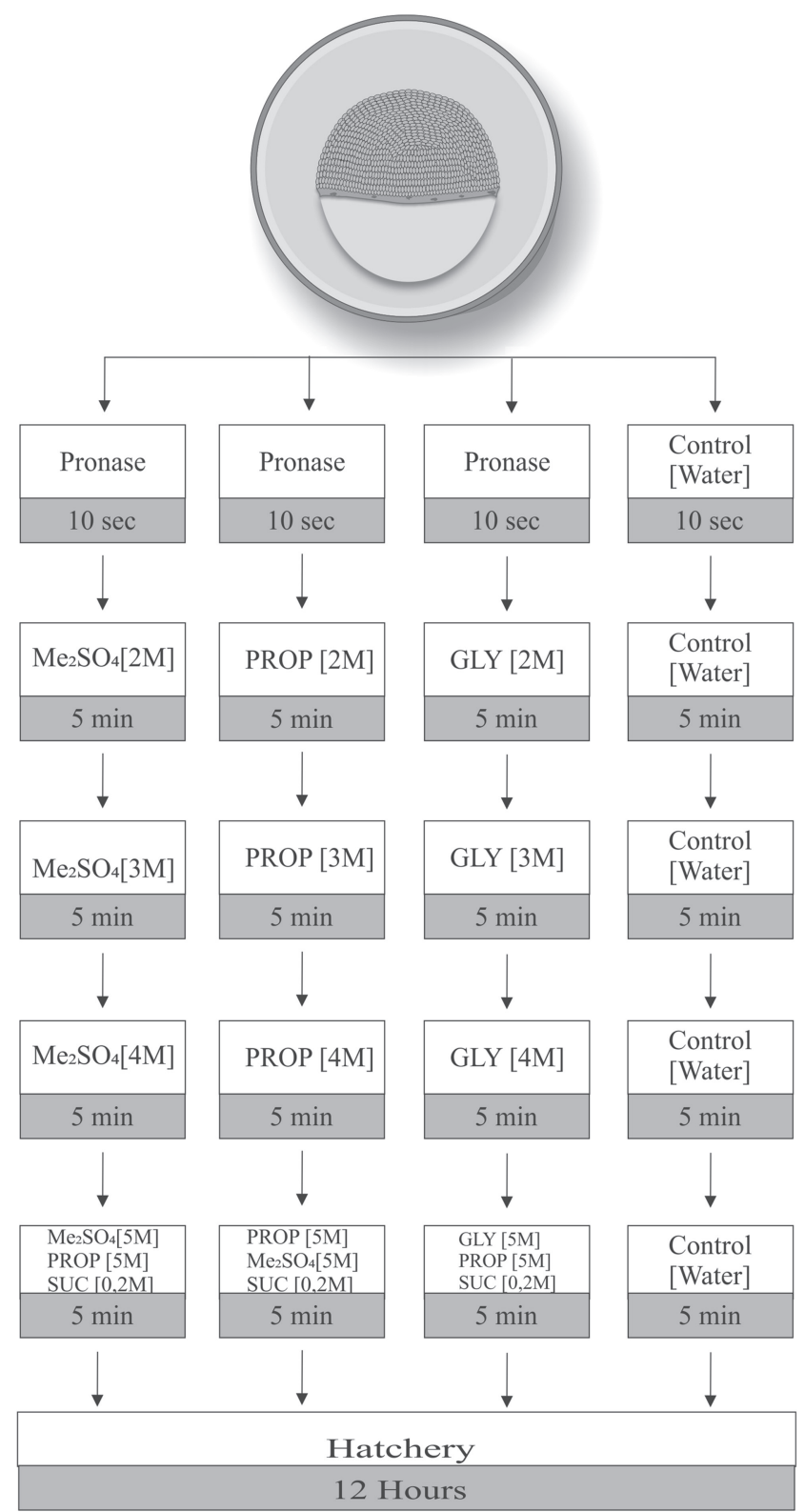

Fig. 1. Experimental design of sensitivity test to cryoprotectant protocols for Prochilodus lineatus embryos $\left(28 \pm 1^{\circ} \mathrm{C}\right)$. Dimethyl sulfoxide - $\mathrm{Me}_{2} \mathrm{SO}_{4} ; 1,2$-Propanediol PRO; Glycerol - GLY; Sucrose - SUC; Pronase - Pronase-E; Second - sec; Minute - min.

Cooling protocols. Based on the results of the "sensitivity to cryoprotectants", we selected two methodologies to expose the embryos at low temperatures. The embryos were exposed to two main internal cryoprotectant methodologies $\left(\mathrm{Me}_{2} \mathrm{SO}_{4}\right.$ and PROP) according to the Fig. 1. After the fourth step, these embryos still immersed in the final cryoprotectant solution, were exposed for a period of 12 hours, at temperatures of 0 and $5^{\circ} \mathrm{C}$ (BOD Cienlab CE-300). After this period, the embryonic temperature was increased gradually until reaching the ambient temperature $\left(28 \pm 1^{\circ} \mathrm{C}\right)$, and the embryos were transferred to incubators to continue their development.
Aggressiveness of protocols. Based on the results of the previous tests described, three stages of embryonic development ( $\mathrm{G}, 6 \mathrm{~S}$ and $20 \mathrm{~S})$ were used to evaluate the aggressiveness of the chilling sensitivity tests $\left(5^{\circ} \mathrm{C}\right)$, cryoprotectants toxicity (PROP), and cooling treatment $\left(5^{\circ} \mathrm{C}\right.$ and PROP). Each evaluation followed its respective protocol described above. After this period, the embryos were transferred to incubators to continue their development for a period of 12 hours.

Morphologic trials. Embryos were collected $12 \mathrm{~h}$ after treatments and fixed in 4\% paraformaldehyde, $2 \%$ glutaraldehyde, and $0.1 \mathrm{M}$ Sorensen phosphate buffer, $\mathrm{pH}$ 7.2 for light microscopy analysis.

A portion of samples was stained with hematoxylin and analyzed "in toto" under a Motic SMZ-168 stereomicroscope, photographed with a Moticam 2500 5.0-megapixel camera and Motic Images Plus 2.0 software. The other portion was subjected to light microscopy and the biological material embedded in glycol methacrylate (Technovit 7100/ historesin) and sectioned into $3 \mu \mathrm{m}$-thick slices. Later, they were stained with toluidine blue, hematoxylin-eosin, and periodic acid-Schiff (PAS).

Statistical analysis. All treatments were performed in a completely randomized design with three replicates containing $139 \pm 11$ embryos per sample. In each sample, the number of live larvae (survival) was estimated after $12 \mathrm{~h}$ treatments. The viable or normal larvae and unviable larvae that presented deformities, such as curved notochord, reduced body size, and abnormal fins, were also quantified. To examine the level of interaction between variables, we used the $\mathrm{R}$ statistical program, performing Bartlett and Shapiro-Wilk tests, followed by ANOVA and Tukey's test $(\mathrm{a}=0.05)$.

Ethics statement. All procedures included in this work comply with the Princípios Éticos de Experimentação Animal, protocol no. 05/2013/CEUA, adopted by the Colégio Brasileiro de Experimentação Animal (COBEA), and were approved by the Comissão de Ética no Uso de Animais (CEUA), Faculdade de Engenharia, UNESP/Ilha Solteira, São Paulo, Brazil.

\section{Results}

Prochilodus lineatus embryos were sensitive to low temperature exposure $\left(0\right.$ and $\left.5^{\circ} \mathrm{C}\right)$ in $\mathrm{G}$ stage $(p<0.05)$, presented more resistance at the advanced development stages (Fig. 2a). At $5^{\circ} \mathrm{C}$, a higher survival percentage was observed at all evaluated embryonic stages, whereas embryos at phase $20 \mathrm{~S}$ displayed no statistically significant difference in survival compared with controls. After storage between 0 and $5^{\circ} \mathrm{C}$, embryos at $\mathrm{G}$ and $6 \mathrm{~S}$ phases had a lower relative survival rate $(p<0.05)$ than those at the $20 \mathrm{~S}$ phase (Fig. 2a). 
Evaluation of cryoprotectant protocol toxicity demonstrated that treatments using GLY as a cryoprotectant were associated with a lower survival rate $(p<0.05)$ than other treatments (Fig. 2b). Treatments based on PROP and $\mathrm{Me}_{2} \mathrm{SO}_{4}$ at $6 \mathrm{~S}$ and $20 \mathrm{~S}$ phases provided a statistically higher survival percentage than those at $\mathrm{G}$ phase (Fig. 2b). Increased resistance to protocol exposure was directly proportional to embryonic development.

Evaluating cooling in the $G$ phase, a similar relative survival percentage as observed in the control was found only for treatment with PROP at $5^{\circ} \mathrm{C}$ (Fig. $2 \mathrm{c}$ ). At $5^{\circ} \mathrm{C}$, both cryoprotectants in the $6 \mathrm{~S}$ phase gave a high survival percentage, whereas only the PROP treatment did so at $0^{\circ} \mathrm{C}$ (Fig. 2c). At the $20 \mathrm{~S}$ stage, survival greater than 70 percentages was observed in all treatments, but at $5^{\circ} \mathrm{C}$, neither PROP nor $\mathrm{Me}_{2} \mathrm{SO}_{4}$ differed significantly from the control. During the cooling tests, embryonic resistance could be observed to increase in the more advanced stages (Fig. 2c).

Individual exposure to low temperatures was more detrimental to embryonic development in P. lineatus (Fig. 2d) than exposure to cryoprotectants, although both significantly interfered with early embryonic development. However, when associated with cooling treatment, an increase in embryonic
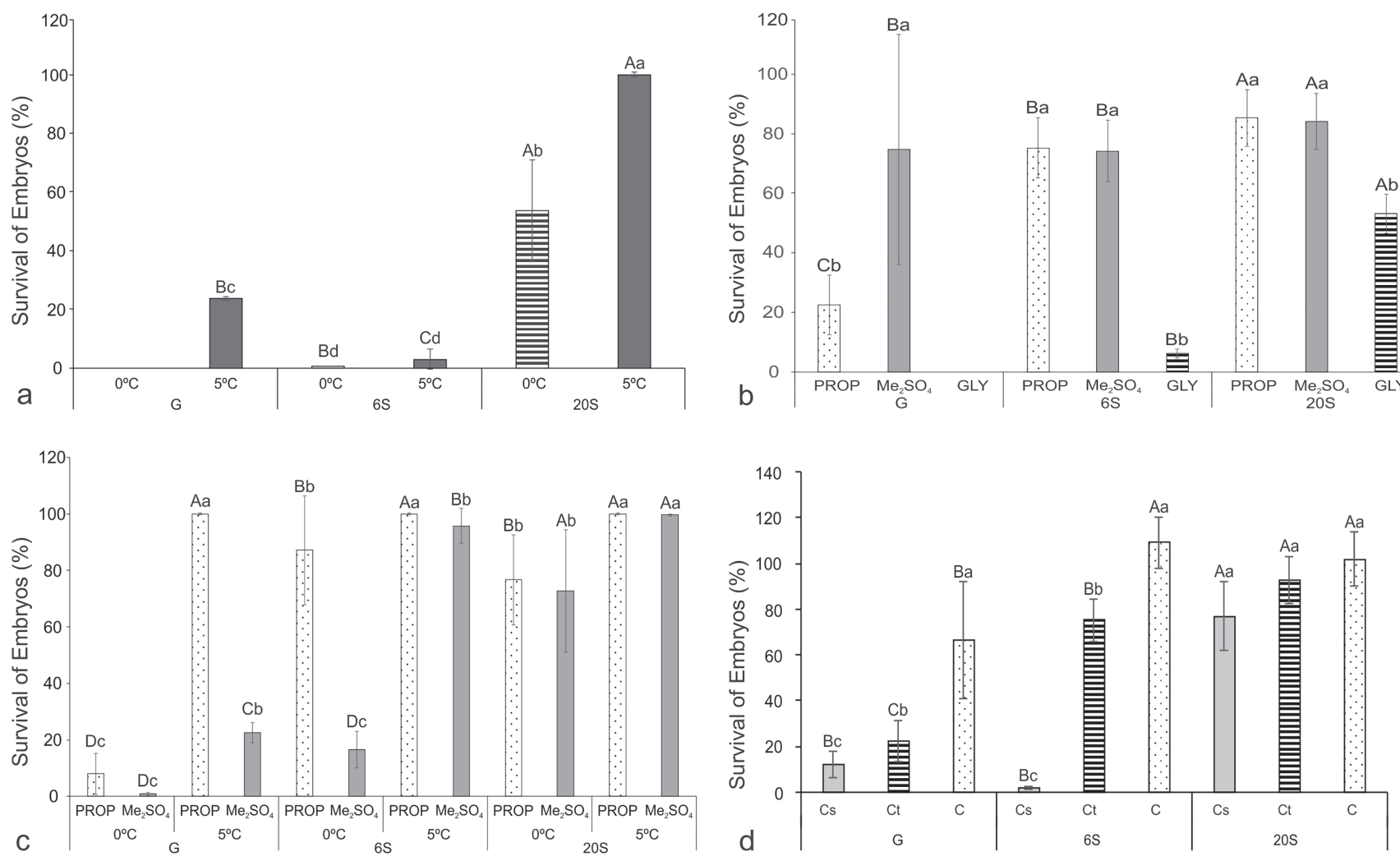

Fig. 2. Relative survival of Prochilodus lineatus embryos. a. Chill sensitivity - ( 0 and $\left.5^{\circ} \mathrm{C}\right)$; b. Sensitivity to cryoprotectant protocols; c. Cooling protocols; d. Aggressiveness of protocols: chilling sensitivity x cryoprotectants toxicity x cooling protocols. Gastrula stage (G); 6 somites stage (6S); 20 somites stage (20S); Dimethyl sulfoxide - $\mathrm{Me}_{2} \mathrm{SO}_{4}$; 1,2-Propanediol - PROP; glycerol - GLY; Chilling sensitivity - Cs; cryoprotectants toxicity (PROP - 1,2-Propanediol) - Ct; cooling treatment - C. Lowercase letters compare statistically, in the same stages of development. Capital letters compare statistically the same protocols between three stages of development. All samples contained $139 \pm 11$ embryos. Data are presented as the mean percentage relative to control $\pm \mathrm{SD}$ (considering the control as $100 \%)$. Correction index: $\log (\mathrm{x}+1)$. 

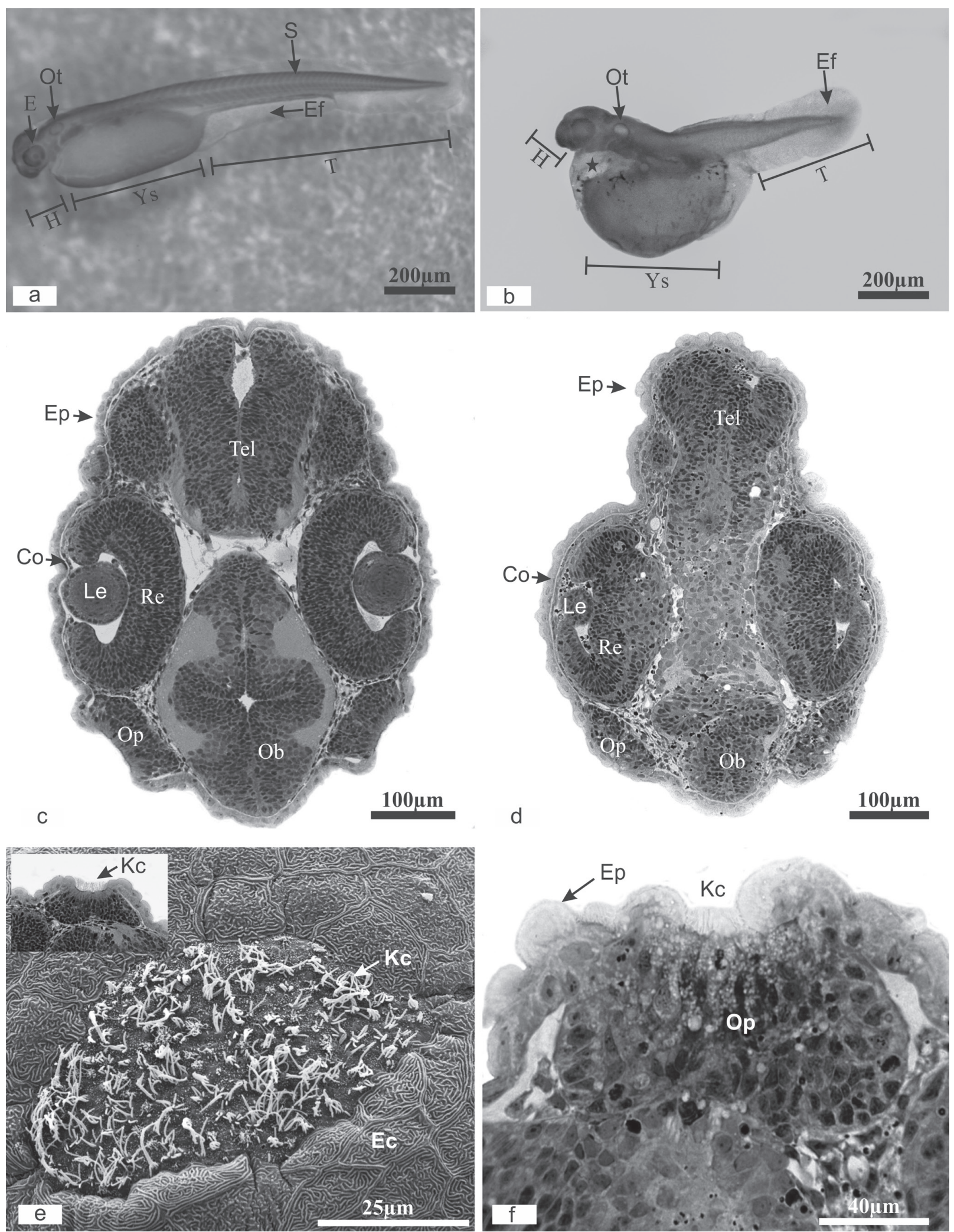

Fig. 3. Morphological analysis of Prochilodus lineatus embryos after cooling protocols. a. Normal embryo (control) - Viable embryo; b. Abnormal embryo - unviable embryo; transverse sections through the head: c. Normal embryo, d. Abnormal embryo; e. Kinocilia in placode olfactory (inset - normal embryo); and f. Placode olfactory of abnormal embryo. Tail - T; Head - H; Yolk sac - Ys; Eye - E; Somite - S; Embryonic fin - Ef; Yolk retraction - star; Otic vesicle - Ot; Lens - Le; Retina - Re; Vitreous body and aqueous cavities - asterisk; Transparent cornea - Co; Olfactory placode - Op; Telencephalon - Te; Olfactory bulb - Ob; Epithelium - Ep; Kinocilia in olfactory placode - Kc; and Epidermal cell - Ec. 

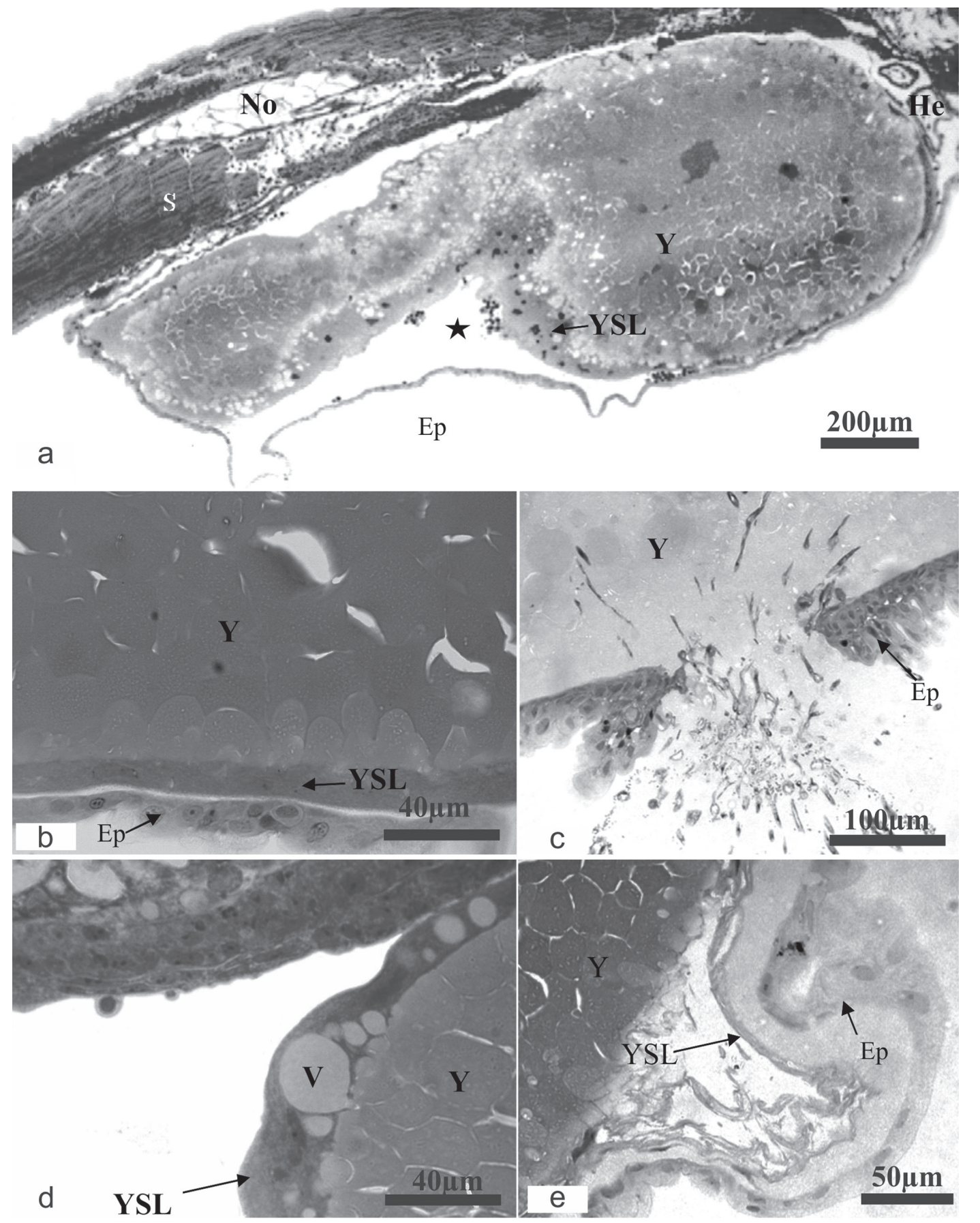

Fig. 4. Morphological analysis of Prochilodus lineatus after cooling treatment. a. Internal retraction of the yolk; b. Normal yolk syncytial layer of Prochilodus lineatus (Control); c. Breaking of membrane; d. Yolk syncytial layer with larger vesicles; and e. Folds in the membrane. Yolk - Y; Somite - S; Heart - He; Epidermal cell - Ec, Notochord - No; Vesicles - V; Yolk syncytial layer -YSL; and Star - retraction of the yolk.

During hatching, embryos have a thin and aligned membrane forming the embryonic fin (Fig. 5a); however, it is possible that damage promoted by cooling treatment enabled the formation of embryonic fins presenting a misshapen cell mass (Fig. 5b). A transverse larval section showed, in control embryos, the existence of two well defined layers, the red and white musculature (Fig. 5c). However, after sensitivity and cooling treatment, this division was not easily visualized (Fig. 5d).

The development of the embryonic musculature occurs via alignment and fusion of myoblasts that give rise to muscular fibers (Fig. 5e), delimited and packed by myosepta (Fig. 5e), forming the somites. In embryos with body curvature and deformed cell mass, myoseptal divisions are incomplete (Fig. 5f), allowing the misaligned fusion of myoblasts (Fig. 5f). 


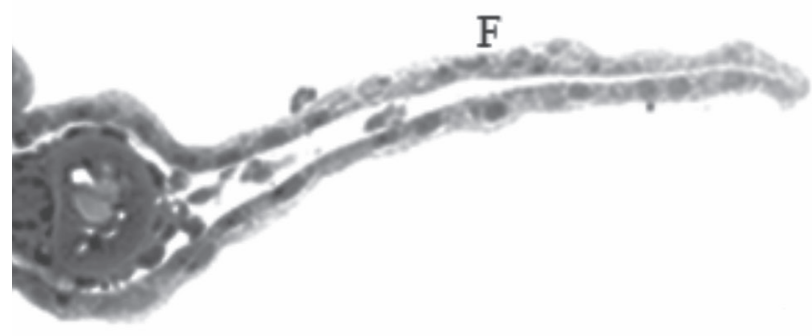

a

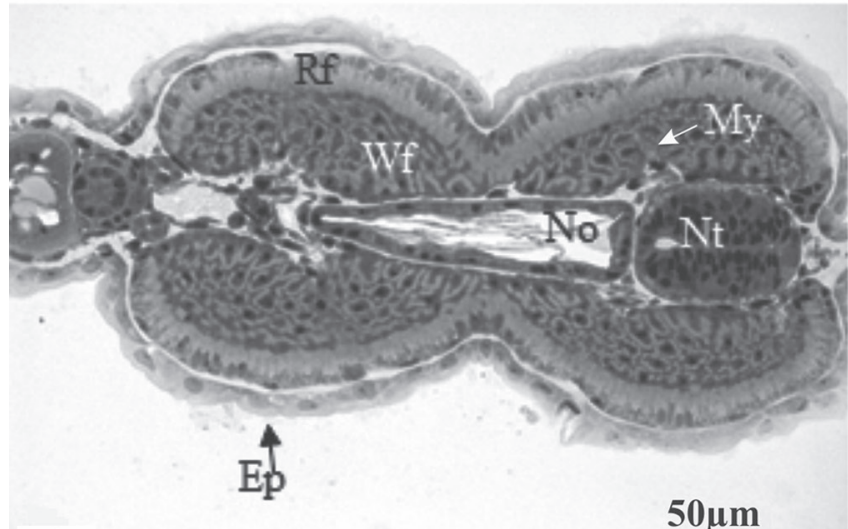

C

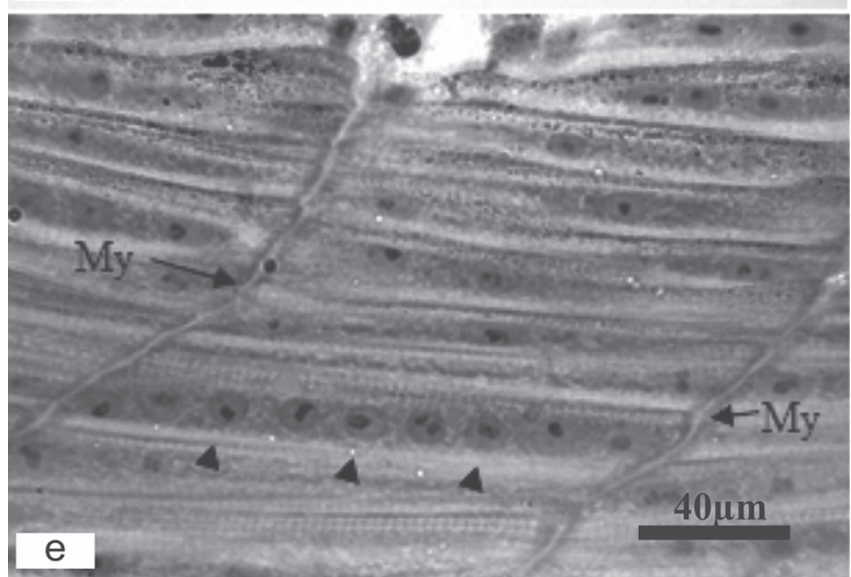

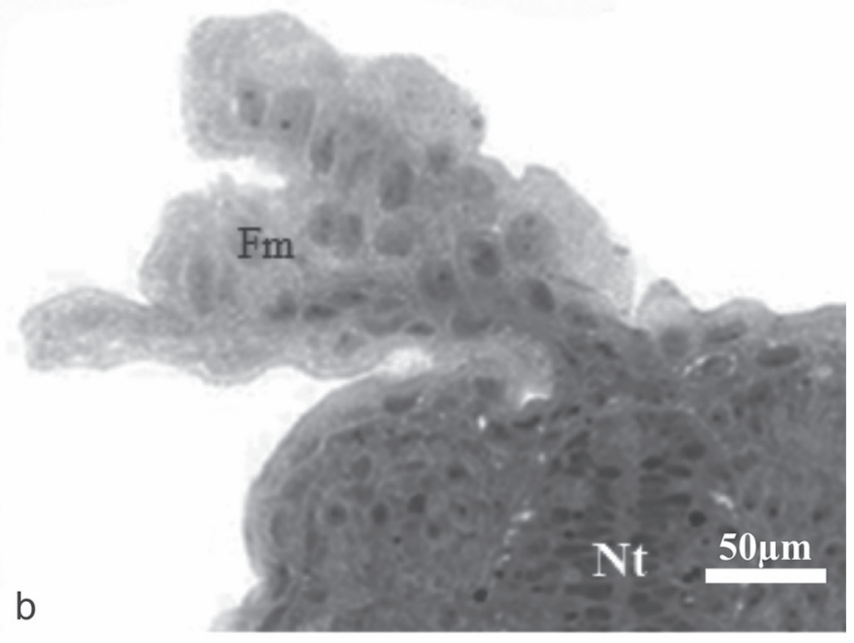
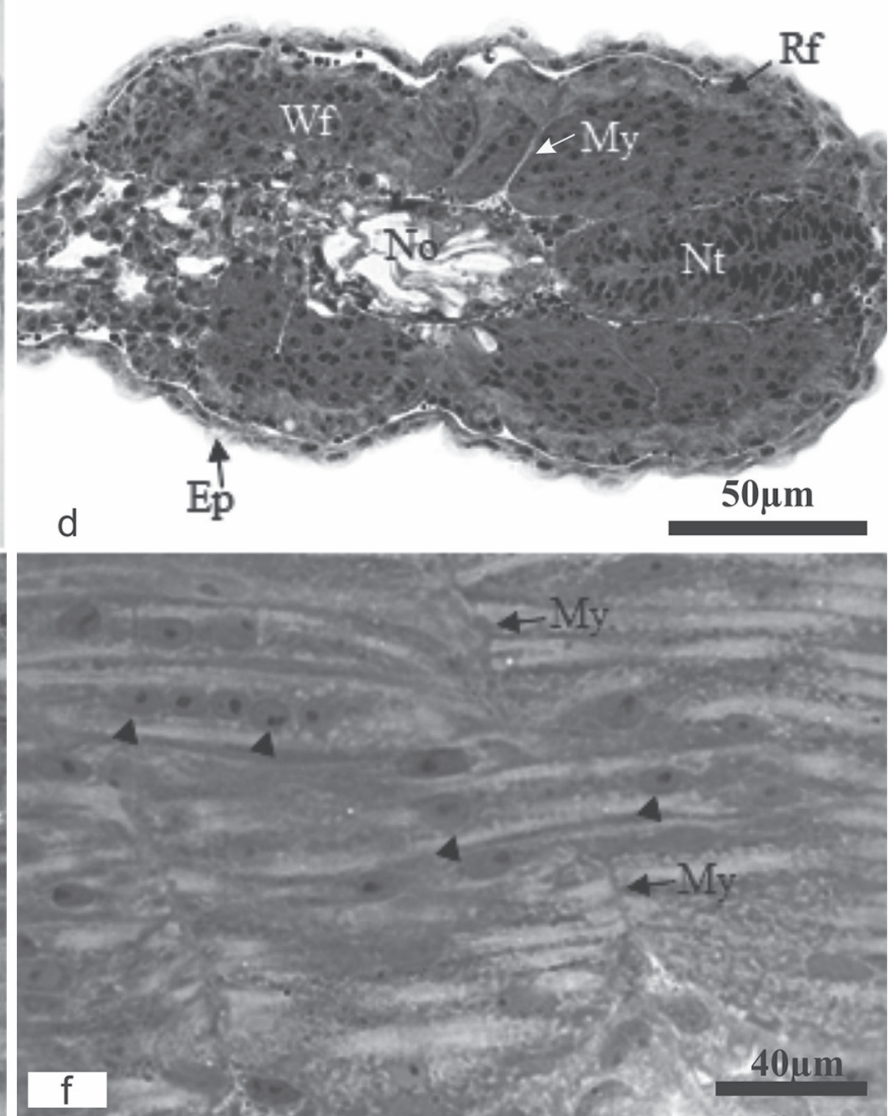

Fig. 5. Morphological analysis of Prochilodus lineatus after cooling treatment. a. Normal embryo fin; b. abnormal embryo fin showing misshapen cell mass; c. Normal embryo tail; d. Abnormal embryo tail. Longitudinal sections of the skeletal muscle: e. Normal development showing alignment of myoblasts for fusion and formation of muscle fiber and somite; and $\mathrm{f}$. Abnormal development, showing discontinuation of myosepta and misalignment of cells for fusion and formation of muscle fiber and somite. Fin - F; Misshapen cell mass in fin - Fm; Notochord - No; Neural tube - Nt; White fibers (fast fibers) - Wf; Red fibers (slow fibers) - Rf; Myosepta - My; Myoblast - arrow head; and Basement membrane - Bm.

When we examined a longitudinal section of the normal embryo (Fig. 6), we observed the presence of an optic vesicle (Figs. 6a, c), containing cells of the macula supporting the otolith (Fig. 6c). However, a high concentration of cells with a turgid core and anomalous morphology, as well as a strong eosin reaction throughout the embryo, could be seen (Figs. $6 \mathrm{~b}, \mathrm{~d})$. The notochord in control individuals extends linearly through the body of the embryo (Fig. 6e); however, in individuals with a curved body or a large amount of deformed cellular mass, the notochord appears curved (Fig. 6f). 

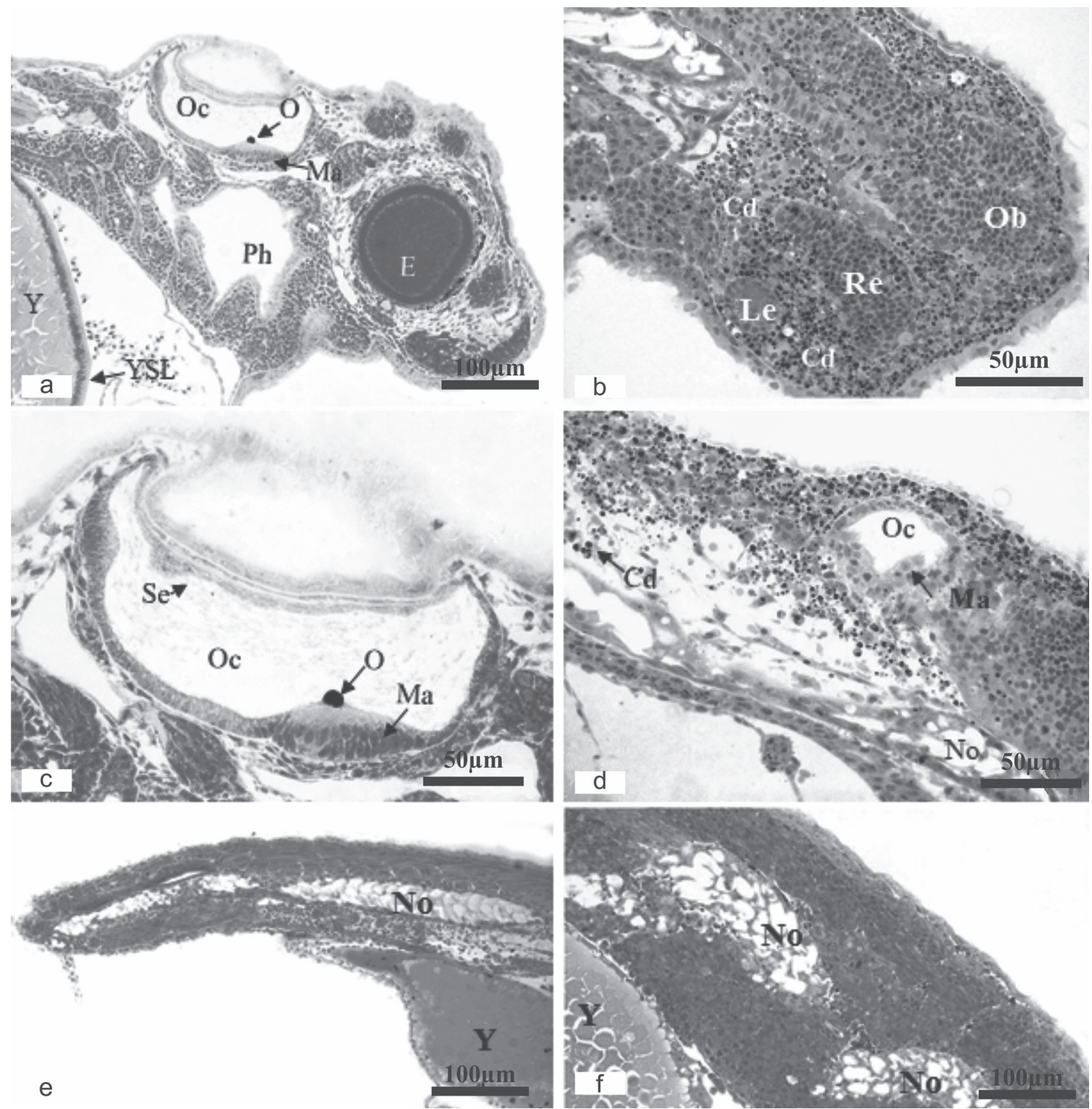

Fig. 6. Morphological analysis of Prochilodus lineatus after cooling protocols. a. Normal embryo head (control); b. Abnormal embryo head showing numerous dead cells. Longitudinal sections; c. Otic vesicle in normal development; d. Otic vesicle in abnormal development; e. Alignment of notochord in normal development; and f. Misalignment of notochord in abnormal development (bend in the notochord). Yolk - Y; Pharynx - Ph; Otolith chamber filled with endolymph - Oc; Squamous epithelium - Se; Otolith - O; Cell death - Cd; Macula (sensory epithelium) - Ma; Somite - S; Heart - He; Epidermal cell - Ec, Notochord - No; and Yolk syncytial layer - YSL.

\section{Discussion}

Exposure techniques and maintenance of fish embryos at low temperatures promotes serious embryo injuries, even with no formation of large ice crystals (Liu et al., 2001; Fornari et al., 2012; Neves et al., 2012). For $P$. lineatus embryos, these morphological changes could be verified in all treatments through a high amount of cell death, morphological deformities, and low survival rates in the early stages.

Despite the high sensitivity to cold reported in the literature for temperate climate fish species, such as
Sciaenops ocellatus and Tinca tinca (Gwo et al., 1995; ElBattawy, Linhart, 2009), and neotropical species, such as Piaractus mesopotamicus (Neves et al., 2012; Lopes et al., 2013), cooling protocols use temperatures below or close to $0^{\circ} \mathrm{C}$ in their attempt to prolong embryonic development by long periods (Ninhaus-Silveira et al., 2006; Fornari et al., 2012). Thus, in this study, it was found that the use of a higher temperature $\left(5^{\circ} \mathrm{C}\right)$ allowed an increase in tropical fish embryonic survival and prolonged embryonic development time sufficiently to achieve a 12-h cooling technique, although morphological damage could not be controlled. 
Normally, the use of low temperatures is associated with the use of cryoprotectants, which minimize the damage caused by cold (Carpenter, Crowe, 1988; Hagedorn et al., 1997a), ensuring, for example, the activity of the enzymes LDH (lactate dehydrogenase) and G-6-PDH (glucose 6 phosphate dehydrogenase), essential for embryonic development (Carpenter, Crowe, 1988; Adams et al., 2005). However, when cryoprotectant concentration exceeds the maximum levels tolerated by a species, serious toxicological effects are generated, resulting in morphological damage or even in embryonic death (Suzuki et al., 1995; Hagedorn et al., 1997a; Dinnyés et al., 1998).

The possible effects of this excess were observed in this study, generating embryos with morphological anomalies. The cryoprotectant solutions, which used $\mathrm{Me}_{2} \mathrm{SO}_{4}$ and PROP as base substances, were less toxic to $P$. lineatus embryos and are widely used in cryopreservation tests because of the low toxicity of internal cryoprotectants (Zhang, Rawson, 1998; Lahnsteiner, 2008) when used alone; however, mixtures of cryoprotectants at low concentrations can result in a survival rate below 50\% (Lahnsteiner, 2008).

Although high mortality rates during tests of chilling sensitivity and cryoprotectant toxicity were observed in the stage three of development, it was noted that combinations of these variables during the cooling process resulted in greater survival rates. It is believed that reduction in temperature results in a rearrangement of lipids in biological membranes, which reduces their fluidity (Ghetler et al., 2005; Kučerka et al., 2011) and consequently, their permeability to cryoprotectants. Furthermore, the amount of cryoprotectant that diffuses through the membrane is associated with a low embryo metabolism generated by reduced temperature, which allows preservation of biological structures. Thus, our results demonstrate the need to use cryoprotectant solution in treatments that do not involve the formation of ice.

In addition to the variables listed above, it was found that the embryonic stages studied here responded differently to treatment effects, being more sensitive to treatment in the early stages of development and resistant in the advanced stages. This is commonly reported in the literature (Zhang, Rawson, 1998; Lahnsteiner, 2008), which leads us to consider later stages as the best biological models for evaluation under low temperatures and the influence of cryoprotectants (PROP and $\mathrm{Me}_{2} \mathrm{SO}_{4}$ ).

However, later developmental stages adopted a complex embryonic structure, marked by higher morphologic compartmentalization (Ninhaus-Silveira et al., 2007; Alexandre et al., 2009). This morphology was one characteristic that could render freezing or vitrification techniques infeasible due to the great difficulty of water and cryoprotectant diffusion during the cryogenic process and different water concentrations in embryonic regions (Hagedorn et al., 1997b, 1998). It is believed that, at advanced stages, these large morphological differences, such as in zebrafish, where yolk fluid and blastoderm rates reach $42 \%$ and $82 \%$, respectively (Hagedorn et al., 1997b), generate different needs and care, which so far are impractical.
Despite the high survival rates in cooling treatment, all treatments promoted frequent damage to embryonic formation, generating morphologically unviable larvae without the ability to perform vigorous swimming, which results in low survival in natural environments. Thus, evaluation of not only survival rates but also larvae conditions after a period is of utmost importance to validate the protocols tested. This was also proven in Piaractus mesopotamicus embryos that showed numerous deformities after freezing treatments (Neves et al., 2012).

The YSL is a histological embryonic structure used to investigate freezing effects on the basis of its integrity. When the cooling process does not preserve its morphophysiology, the YSL develops an irregular shape that can be found in atypical locations (Ninhaus-Silveira et al., 2008; Neves et al., 2012;). This layer is a transition between two different biological tissues, which present different water and permeability rates and amounts of dry matter (Hagedorn et al., 1997a, 1998; Routray et al., 2002). Thus, it is believed that any volumetric variation in the blastoderm not accompanied by vitelline mass, such as dehydration, would be felt first by the YSL, which would be subjected to a greater force at the blastoderm than the yolk, possibly leading to deformities such as bending, breaking, and detachment. Even the diffusion rate being greater in the blastoderm than in the yolk sac region (Suzuki et al., 1995), it was not possible prevent morphological changes such as misshapen cell masses and high cell death proportion.

The malformation of embryonic structures observed with our treatments was probably influenced by the performance of cryoprotectant solutions, which have chemical characteristics deleterious to development. In cryoprotectant datasheets, manufacturers have warned of their effects on embryonic development and other features that could cause damage to biological material. $\mathrm{Me}_{2} \mathrm{SO}_{4}$ can promote mutations in mammalian somatic cells, malformation of the skeletal muscle system, and atrophy or abortion in rats (Sigma-Aldrich, 2016a). PROP may cause changes in the spleen, skin irritation, and central nervous system suppression (Sigma-Aldrich, 2016b). In this way, it becomes probable that a large number of the dead cells found in our larvae and misaligned fusion of myoblasts during the myogenesis process were derived from embryo contact with cryoprotectants. However, the relationship between temperature and cryoprotectants with morphological damage arising from cooling treatment requires more specific studies.

These results indicate that although organogenesis at the $20 \mathrm{~S}$ stage is the most resistant to cryopreservation treatments, the use of PROP associated with $5^{\circ} \mathrm{C}$ temperature enables a high survival rate for all stages of $P$. lineatus embryonic development. However, the cooling protocols evaluated were not effective, shows that high cryoprotectant concentrations promote numerous morphological lesions, compromising normal embryonic development. 


\section{Acknowledgments}

This work was supported by the Centro Nacional de Pesquisa e Conservação de Peixes Continentais - CEPTA/ ICMBIO, which provided the fish and the facilities used in this study; and by the Conselho Nacional de Desenvolvimento Científico e Tecnológico (CNPq).

\section{References}

Adams SL, Zhang T, Rawson DM. The effect of external medium composition on membrane water permeability of zebrafish (Danio rerio) embryos. Theriogenology. 2005; 64(7):1591-602.

Alexandre JS, Ninhaus-Silveira A, Veríssimo-Silveira R, Buzollo H, Senhorini JA, Chaguri MP. Structural analysis of the embryonic development in Brycon cephalus (Günther, 1869). Zygote. 2009; 18(2):173-83.

Carpenter JF, Crowe JH. The mechanism of cryoprotection of proteins by solutes. Cryobiology. 1988; 25(3):244-55.

Castro RMC, Casatti L, Santos HF, Melo ALA, Martins LSF, Ferreira KM et al. Estrutura e composição da ictiofauna de riachos da bacia do Rio Grande no estado de São Paulo, Sudeste do Brasil. Biota Neotrop. 2004; 4(1):1-12.

Desai K, Spikings E, Zhang T. Use of methanol as cryoprotectant and its effect on sox genes and proteins in chilled zebrafish embryos. Cryobiology. 2015; 71(1):1-11.

Dinnyés A, Urbányi B, Baranyai B, Magyary I. Chilling sensitivity of carp (Cyprinus carpio) embryos at different developmental stages in the presence or absence of cryoprotectans: work in progress. Theriogenology. 1998; 50(1):1-13.

El-Battawy K, Linhart O. Preliminary studies on cryopreservation of common tench (Tinca tinca) embryos (work in progress). Reprod Domest Anim. 2009; 44(4):718-23.

Fornari DC, Ribeiro RP, Streit-Jr D, Godoy LC, Neves PR, Oliveira D, Sirol RN. Effect of cryoprotectants on the survival of cascudo preto (Rhinelepis aspera) embryos stored at $-8{ }^{\circ} \mathrm{C}$. Zygote. 2011; 22(1):58-63.

Fornari DC, Ribeiro RP, Streit-Jr DP, Vargas L, Godoy LC, Oliveira CAL, Digmayer M, Galo JM, Neves PR. Increasing storage capability of pacu (Piaractus mesopotamicus) embryos by chilling: development of a useful methodology for hatcheries management. Cryo-Lett. 2012; 33(2):126-34.

Ghetler Y, Yavin S, Shalgi R, Arav A. The effect of chilling on membrane lipid phase transition in human oocytes and zygotes. Hum Reprod. 2005; 20(12):3385-89.

Gwo JC, Strawn K, Arnold CR. Changes in mechanical tolerance and chilling sensitivity of red drum (Sciaenopus ocellatus) embryos during development. Theriogenology. 1995; 43(7):1155-61.

Hagedorn M, Kleinhans FW, Artemov D, Pilatus U. Characterization of a major permeability barrier in the zebrafish embryo. Biol Reprod. 1998; 59(5):1240-50.

Hagedorn M, Kleinhans FW, Freitas R, Liu J, Hsu EW, Wildt DE, Rall WF. Water distribution and permeability of zebrafish embryos, Brachydanio rerio. J Exp Zool, Part A. 1997a; 278(6):356-71.

Hagedorn M, Kleinhans FW, Wildt DE, Rall WF. Chill sensitivity and cryoprotectant permeability of dechorionated zebrafish embryos, Brachydanio rerio. Cryobiology. 1997b; 34(3):251-63.

Harvey B, Kelley RN, Ashwood-Smith MJ. Permeability of intact and dechorionated zebra fish embryos to glycerol and dimethyl sulfoxide. Cryobiology. 1983; 20(4):432-39.
Isayeva A, Zhang T, Rawson DM. Studies on chilling sensitivity of zebrafish (Danio rerio) oocytes. Cryobiology. 2004; 49(2):114-22.

Kučerka N, Nieh MP, Katsaras J. Fluid phase lipid areas and bilayer thicknesses of commonly used phosphatidylcholines as a function of temperature. Biochim Biophys Acta, Biomembr. 2011; 1808(11):2761-71.

Lahnsteiner F. The effect of internal and external cryoprotectants on zebrafish (Danio rerio) embryos. Theriogenology. 2008; 69(3):384-96.

Liu XH, Zhang T, Rawson DM. Effect of cooling rate and partial removal of yolk on the chilling injury in zebrafish (Danio rerio) embryos. Theriogenology. 2001; 55(8):1719-31.

Lopes TS, Streit-Jr DP, Fornari DC, Oliveira D, Ribeiro RP, Romagosa E. Chilling curves for Piaractus mesopotamicus (Holmberg, 1887) embryos stored at $-8^{\circ} \mathrm{C}$. Zygote. $2013 ; 21(4): 345-50$.

Neves PR, Ribeiro RP, Streit-Jr DP, Natali MRM, Fornari DC, Santos AI, Godoy LC. Injuries in pacu embryos (Piaractus mesopotamicus) after freezing and thawing. Zygote. 2012; 22(1):25-31.

Ninhaus-Silveira A, Foresti F, Azevedo A. Structural and ultrastructural analysis of embryonic development of Prochilodus lineatus (Valenciennes, 1836) (Characiformes: Prochilodontidae). Zygote. 2006; 14(3):217-29.

Ninhaus-Silveira A, Foresti F, Azevedo A, Agostinho CA, Veríssimo-Silveira R. Cryogenic preservation of embryos of Prochilodus lineatus (Valenciennes, 1836) (Characiformes: Prochilodontidae). Zygote. 2008; 17(1):45-55.

Ninhaus-Silveira A, Foresti F, Azevedo A, Agostinho CA, VeríssimoSilveira R. Structural and ultrastructural characteristics of the yolk syncytial layer in Prochilodus lineatus (Valenciennes, 1836) (Teleostei: Prochilodontidae). Zygote. 2007; 15(3):267-71.

Oliveira-Almeida IR, Buzollo H, Costa RS, Veríssimo-Silveira R, Porto-Foresti F, Ninhaus-Silveira A. Structural analysis of embryogenesis of Leiarius marmoratus (Siluriformes: Pimelodidae). Zygote. 2014; 14(3):1-16.

Robles V, Cabrita E, Acker JP, Herráez P. Embryo cryopreservation: What we know until now. In: Cabrita E, Robles V, Herráez $\mathrm{P}$, editors. Methods in reproductive aquaculture: Marine and freswater species. New York: CRC Press; 2009. p.265-294.

Robles V, Cabrita E, Real M, Álvarez R, Herráez M. Vitrification of turbot embryos: preliminary assays. Cryobiology. 2003; 47(1):30-39.

Routray P, Suzuki T, Strüssmann CA, Takai R. Factors affecting the uptake of DMSO by the eggs and embryos of medaka, Oryzias latipes. Theriogenology. 2002; 58(8):1483-96.

Sigma-Aldrich Co. Safety Data Sheet - Dimethyl sulfoxide (product number D2650); 2016a [updated 2016 Jan 18; cited 2016 Jun 16]. Available from: http://www.sigmaaldrich.com.

Sigma-Aldrich Co. Safety Data Sheet - 1,2-Propanodiol (product number 398039); 2016b [updated 2014 Dec 01; cited 2016 Jun 16]. Available from: http://www.sigmaaldrich.com.

Suzuki T, Komada H, Takai R, Arii K, Kozima TT. Relation between toxicity of cryoprotectant DMSO and its concentration in several fish embryos. Fisheries Sci. 1995; 61(2):193-97.

Zhang T, Rawson DM. Permeability of dechorionated one-cell and six-somite stage zebrafish (Brachydanio rerio) embryos to water and methanol. Cryobiology. 1998; 37(1):13-21.

Zhang T, Rawson DM. Studies on chilling sensitivity of zebrafish (Brachydanio rerio) embryos. Cryobiology. 1995; 32(3):239-46.

Submitted April 24, 2017 Accepted June 22, 2017 by Bernardo Baldisserotto 